\title{
Findings on the role of cooperatives in local economic development in Buffalo City Metropolitan Municipality: A participatory monitoring and evaluation approach
}

\begin{tabular}{|c|c|}
\hline \multicolumn{2}{|c|}{$\begin{array}{l}\text { Authors: } \\
\text { Fundiswa Gxabuza }{ }^{1} \text { (D) } \\
\text { Ogochukwu Nzewi }{ }^{1}\end{array}$} \\
\hline \multicolumn{2}{|c|}{$\begin{array}{l}\text { Affiliations: } \\
\text { 'Department of Public } \\
\text { Administration, Faculty of } \\
\text { Management and Commerce, } \\
\text { University of Fort Hare, } \\
\text { Bisho, South Africa }\end{array}$} \\
\hline \multicolumn{2}{|c|}{$\begin{array}{l}\text { Research Project Registration: } \\
\text { Project Number: } \\
\text { NZE031SGXA01 }\end{array}$} \\
\hline \multicolumn{2}{|c|}{$\begin{array}{l}\text { Corresponding author: } \\
\text { Fundiswa Gxabuza, } \\
\text { fundiswa.gxabuza@eccogta. } \\
\text { gov.za }\end{array}$} \\
\hline \multicolumn{2}{|c|}{$\begin{array}{l}\text { Dates: } \\
\text { Received: } 21 \text { Feb. } 2010 \\
\text { Accepted: } 06 \text { Oct. } 2020 \\
\text { Published: } 25 \text { Jan. } 2021\end{array}$} \\
\hline \multicolumn{2}{|c|}{$\begin{array}{l}\text { How to cite this article: } \\
\text { Gxabuza, F.G. \& Nzewi, O., } \\
\text { 2021, 'Findings on the role } \\
\text { of cooperatives in local } \\
\text { economic development in } \\
\text { Buffalo City Metropolitan } \\
\text { Municipality: A participatory } \\
\text { monitoring and evaluation } \\
\text { approach', Africa's Public } \\
\text { Service Delivery and } \\
\text { Performance Review 9(1), } \\
\text { a387. https://doi.org/ } \\
\text { 10.4102/apsdpr.v9i1.387 }\end{array}$} \\
\hline \multicolumn{2}{|c|}{$\begin{array}{l}\text { Copyright: } \\
\text { (C) 2021. The Authors } \\
\text { Licensee: AOSIS. This } \\
\text { is licensed under the } \\
\text { Creative Commons } \\
\text { Attribution License. }\end{array}$} \\
\hline \multicolumn{2}{|l|}{ Read online: } \\
\hline  & $\begin{array}{l}\text { Scan this QR } \\
\text { code with your } \\
\text { smart phone or } \\
\text { mobile device } \\
\text { to read online. }\end{array}$ \\
\hline
\end{tabular}

\begin{abstract}
Background: This article outlines the role of cooperatives in local economic development (LED) within participatory monitoring and evaluation (PM\&E) approach in the Buffalo City Metropolitan Municipality (BCMM), South Africa. The Department of Trade and Industry acknowledged the inadequacy of monitoring and evaluation (M\&E) of cooperatives. This lack of M\&E of cooperatives' role in LED has also affected cooperatives in BCMM.
\end{abstract}

Aim: The study sought to establish the contributory role of cooperatives in promoting LED outcomes and to determine the extent to which the PM\&E was capable of capacitating cooperatives.

Setting: The study is based in East London and the target population is primary cooperatives. Primary cooperatives are defined by Buffalo City Integrated Cooperative Development Strategy (ICDS) as cooperatives that have at least five members, with an aim of providing employment to members.

Methods: The research design for the study is exploratory and inductive. The study adopted qualitative research approach that combines participatory action research (PAR) and PM\&E. Two sets of data collection such as focus group interviews (FGIs) and e-mailed questionnaire (EQ) were used.

Results: It was established that cooperatives have not yet achieved their contributory role of promoting LED, specifically in terms of job creation.

Conclusion: Based on the findings it was recommended that capacity building and training with regard to M\&E should not focus on conventional M\&E, but rather on PM\&E, where cooperatives become involved in the M\&E of their business.

Keywords: cooperatives; participatory monitoring and evaluation; pilot study; local economic development; job creation; poverty alleviation.

\section{Introduction}

The government of South Africa intended to halve unemployment and poverty by 2014 (Wallis \& Reddy 2012:80). The youth unemployment rate is high, ranging from $51.5 \%$ to $60.3 \%$ (Ismail \& Kollamparambil 2015:301). The Department of Economic Development and Environmental Affairs (DEDEA 2008:5) stated it clearly that the Eastern Cape Province is no exception, as it currently faces high unemployment and widespread poverty, and citizens desperately need work to earn a living. This situation necessitates urgent innovative development strategies, including employment generation strategies. The Buffalo City Metropolitan Municipality (BCMM) has strived to alleviate poverty through the development of local economic development (LED) strategies, inclusive of cooperative strategy. However, the magnitude of challenges outlined have sharply raised the issues of unemployment, job creation and poverty alleviation. Research on cooperatives has focussed on their role as agents of development in rural areas, poverty alleviation and unemployment (Abrahams 2009; Manciya 2012; Mtshwelo 2014; Vellem 2012). Some have advanced information on worker cooperatives and shared lessons on successes and failures (Eckert 2007). Indeed, not much has been reported on successes, specifically on how cooperatives have fulfilled the outcomes of LED (Wallis \& Reddy 2012:71). The Department of Trade and Industry (DTI), whilst acknowledging the need for evaluation of the impact of government policy and strategies for cooperative development (DTI 2004:22), also points to the lack of monitoring 
and evaluation of cooperatives as a critical challenge, which has largely remained inadequate. The significance of the study lies in the knowledge gap on participatory monitoring and evaluation (PM\&E), which should be used as an approach for evaluating the role of cooperatives in LED.

The research study conducted was the role of cooperatives, specifically primary cooperatives in LED within the PM\&E approach, not simply any type of cooperative. The context of these concepts (primary cooperatives and job creation) is briefly defined to set parameters. The working definitions are based on primary cooperatives and job creation. Primary cooperatives were measured as cooperatives formed by five persons with an aim of providing employment services, job creation and employment. Ultimately, this will promote community development (DEDEA 2008:20). On employment creation, the study is more interested in the type of jobs that are created by cooperatives. The type of employment models could be seasonal employment, contract workers or casual workers or temporal work and stable employment. There is also wage employment, where individuals earn as members of cooperatives, as well as maintenance of the steady income by the cooperative (Abrahams 2009:44). In other words, the research will be breaking new ground to get more insight into the topic, which has not been broadly researched (Zeuli \& Deller 2007).

The underlying theoretical framework for the research was empowerment, agency and theory of community development. Barbie and Mouton (2017:322) explained empowerment as enabling participants to be actively involved in supporting or causing advancement of their society in defence of their class or group interest. Strydom and Delport (2011:496) defined empowerment theory as the process of increasing personal, interpersonal, socio-economic and political power that enables people to improve their circumstances. Barbie and Mouton (2017:318) argued that empowerment theory enables participants to actively participate in analysing their status quo. The second theoretical framework is agency theory. Strydom and Delport (2011:493) argued that agency theory provokes an engagement and mobilisation of participants as active agents in the process of creating knowledge and solving their problems. Barbie and Mouton (2017:317) explained agency theory as one in which the researcher is a change agent that supports implementation of participatory action research (PAR) by jointly working with or being a supporter of participants. Terre Blanche, Durrheim and Painter (2006:438) further explained that the collaborative relationship between the researcher and participants hinges on structured transformation and the improvement of the lives of those involved. The last theory is community economic development. This theory is focused more on community development through cooperatives for enhancing social and economic sustainability.

Given the background and articulation of the knowledge gap, the overall aim of the study is to assess the role of cooperatives in LED within the PM\&E approach. The subobjectives of the study are as follows:
- To explore the contributory role of cooperatives in promoting LED as manifested in employment or job creation and poverty alleviation outcomes.

- To apply PM\&E as a research approach in evaluating the role of cooperatives in the BCMM LED strategy and implementation.

- To provide lessons and make recommendations on PM\&E methods and mechanisms that can be utilised in monitoring and evaluating cooperative contributions to LED outcomes.

\section{Research methods and design}

The research design for the study is exploratory and inductive in approach. Bless, Higson-Smith and Sithole (2016:16) defined exploratory research as a design in which limited knowledge or information exists about a particular subject, and it is usually conducted on the basis of gaining a broader understanding of the situation. Neuman (2014:38) elucidated exploratory research as a design that examines a little understood issue for the purpose of developing knowledge about it. The exploratory research design focuses on 'what questions' and takes an investigative stance. The research design has been chosen on the basis of the knowledge gap reported, that is the unknown contribution of cooperatives to LED.

Most participating cooperatives were located in East London, specifically, in the informal settlement of Duncan Village, Scenery Park and Mooiplaas. The municipal and government officials were also based in East London. The study population from which the sample was selected was made up of cooperatives. As a result of the qualitative nature of the study, purposive sampling was fully utilised. Dilshad and Latif (2013:195) recommended purposive sampling for focus groups. De Vos et al. (2011:232) defined purposive sampling as a judgemental sampling in qualitative research, comprising elements that contain the most characteristics of the population that serve the purpose of the study best. For the purpose of obtaining a greater degree of representativeness, stratified sampling has been utilised in selecting participants to respond to e-mailed questionnaire (EQ). The characteristics of participants on stratified sampling were the representativeness by seniority.

The data collection methods used in this study included focus group interview (FGI), EQ and observations. For the pilot study, FGI was conducted with 12 members of the participating cooperative, whilst for the EQ, five participants answered the questionnaire. For the main research, FGIs were conducted with 29 cooperatives. Kumar (2014:156) considered FGI as a relevant data collection tool in qualitative research, that is, particularly interested in thoroughly examining attitudes and opinions towards a certain issue. Du Plooy-Cilliers, Davis and Bezuidenhout (2014:183) further appreciated FGI as they aid in determining the attitudes, perceptions and dislikes of respondents interviewed under the leadership of a researcher who assumes the role of a facilitator. The questions in the interview schedule for the 
FGI were written in both English and IsiXhosa. However, participants were free to express themselves in their mother tongue. This practice was in line with Barbie and Mouton (2017:326), who suggested that the PAR method derives meanings from the vernacular of communication. Mugunya (2002:8) also clearly stated that the role of a researcher is that of a change agent who listens to participants engaged in conversations and sifts the goals and objectives.

For Ali and Birley (1998:4), unlike quantitative data analysis, qualitative data analysis involves the translation of meanings not frequencies. The search for meaning should solicit rich insights into the interpretations of participants. Greeff (2011:373) provided that the analysis of FGI is an integration of numerous elements of qualitative research considering the frequency, context and extensiveness of comments by finding a big idea. The transcription of data was used as recommended by Lacey and Luff (2009:20) as one of the steps to be undertaken in qualitative research studies. Bless et al.'s (2016:339) transcription, then, is one of the fundamentals of qualitative data analysis when listening to stories that participants tell about themselves, as it allows every participant to be understood to have their own experiences. Focus group interviews were recorded using video and digital voice recorders and through capturing notes on flipcharts for the purpose of verifying the repeatability of interpretation.

Subsequent to transcription was coding of research findings in line with research questions and objectives. Maree (2008:105) defined coding as assigning symbols, labels or words when finding a meaningful segment of text in a transcript. Du Plooy-Cilliers et al. (2014:237) defined coding as organising data into 'chunks' by assigning a code to pieces of data that represent an issue relevant to a given research question. It is up to the researcher as to how to compare and group the data in terms of relations pieces based on their similarities and dissimilarities. The researcher should be led by research questions when identifying coding units.

Applications for ethical clearance were submitted to the University of Fort Hare before commencing the pilot study.

\section{Participatory action research}

Pante et al. (2013:423) defined PAR as a participatory and democratic process because of its emphasis on commitment and equality in the research process. It is inclusive in its approach where those affected most by the challenge at hand are actively involved in conducting research. Barbie and Mouton (2017:314) defined PAR as a form of grassroots, bottom-up, participatory research organised on behalf of the underprivileged. The aim is to render a responsive development to the needs of the locals.

\section{Participatory monitoring and evaluation}

Participatory monitoring and evaluation is a process that tracks progress by programme managers and stakeholders
(Sangole et al. 2014:130). In this case, both stakeholders and programme managers have access to information on whether or not project objectives have been met.

\section{Participatory action research and participatory monitoring and evaluation methodological and analytical framework}

Participatory action research was implemented for guiding the facilitation of FGI and motivate participation by participants. Participants were encouraged to actively participate in conducting the research for democratising knowledge creation as suggested by Neuman (2014:30) and take a central role on what is performed as recommended by Bless et al. (2016:89) and empowerment of silent groups by Savin-Baden and Wimpenny (2007:341).

The content of the questions for both the interview schedule and EQ was informed by key features of PM\&E as suggested by various authors listed as follows:

- The Jobes (1997) study on PM\&E guidelines suggested simple steps in PM\&E, namely, setting long-term goals, creating checklist for actions, participatory monitoring and participatory evaluation.

- The study by Sangole et al. (2014:134), Guijt and Hilhorst (2006:30) outlines the steps of Community Driven PM\&E on the development of indicators for measuring progress towards achievement of the objectives. Participants were in charge of data collection, analysis and use results to adjust their activities.

\section{Literature review}

The study is located in Developmental Public Administration. Section 195 of the Constitution alludes to the basic values and principles governing public administration, wherein Section 195(c) emphasises public administration that is development-oriented. Section 195(e) appreciates service delivery that responds to people's needs. Chakrabarty and Chand (2015:5) defined public administration as a broad concept of administration, that is, meant to serve, to look after people or manage their affairs. Du Toit and Van der Walt (2008:8) defined public administration as the rendering of services by the government to the community.

\section{Description of the study population interviewed through focus group interviews and e-mailed questionnaire}

There were four cooperatives specialising in piggery: the first one is located in Zwelitsha, the second in Mdantsane, the third in Mooiplaas (also specialises in general agriculture and catering) and the last in Duncan Village.

There were three cooperatives specialising in poultry farming located, respectively, in Duncan Village (C Section), Zwelitsha and Scenery Park. The first specialises in poultry farming 
specifically related to chicken as a food source. The second specialises in both poultry and piggery. The last specialises in farming chickens and offering garden services.

There were four cooperatives specialising in general agriculture. The first is based in Duncan Village, the second in Cambridge, the third in Scenery Park and the last in Mooiplaas. The Mooiplaas cooperative also specialises in pig farming.

There were three cooperatives specialising in sewing and beading. One is located in Duncan Village, whilst the other two are based in Scenery Park.

There were three cooperatives specialising in catering; two of them also practise piggery and are based in Mooiplaas and Duncan Village, respectively. The other cooperative is based in Duncan Village and also specialises in grass cutting and car washing. Because of a lack of business opportunities, all cooperatives listed in this section are non-operational in terms of catering.

The two remaining cooperatives specialise in other aspects not previously listed. The first is located in Duncan Village and specialises in the manufacturing of soap, ducting, welding and plumbing. The last one specialises with brick making.

The respondents to EQ were two municipal officials and three departmental officials.

\section{Research findings}

This section presents the first research question seeking to measure the contributory role of cooperatives in job creation, specifically, seasonal, contractual, temporary and permanent, as well as maintenance of steady income to members.

\section{Cooperatives and employment creation}

The nature of questions in this regard was highly informed by the literature study by Hertig (2008:1) where cooperatives created 100 million jobs, self-employment and indirect employment. None of the cooperatives have hired any workers. The common challenge with these cooperatives is a lack of market for their products. The challenges in remuneration were mainly attributed to a lack of capital.

\section{Seasonal jobs}

The study by Abrahams (2009) was applied in the evaluation of seasonal jobs created by cooperatives. Only three cooperatives, classified under 'other' created seasonal jobs. The first of these cooperatives specialises in piggery, agriculture and catering in Mooiplaas; the second specialises in sewing and beading and the last specialises in welding, in Duncan Village. For the remaining two cooperatives, the first specialises in grass cutting and the last in sewing, beading and cleaning. The last two cooperatives established that seasonal jobs were tougher to provide. For the cooperative specialising in grass cutting (in Duncan Village), seasonal jobs are scarce during winter.

The cooperative specialising in piggery, agriculture and catering in Mooiplaas has created seasonal jobs only during the maize harvesting season. The second cooperative that specialises in beading and sewing creates seasonal jobs in beading in summer season.

\section{Temporary jobs}

Abrahams (2009:44) defined temporary jobs as jobs created because of the volume of work that is beyond the capacity of the currently available members of cooperatives. The findings revealed that only two cooperatives (i.e. one specialising in poultry, and one specialising in catering and piggery) have managed to create temporary jobs. The cooperative specialising in catering had only created temporary jobs during a catering event. The stipend is solely dependent on the catering and is not guaranteed as an income on a monthly basis.

\section{Contractual jobs}

Only two cooperatives managed to create contractual jobs. The first was based in Scenery Park and specialised in lawn mowing. The second was located in Duncan Village and specialised in sewing and beading.

The first has had only two opportunities to offer contractual employment since its establishment. The study established that the cooperative that was specialising in sewing and beading also struggles in creating and maintaining contractual jobs by itself. The cooperative noted that a certain governmental department requested the beading of a number of bags. That was, however, the first and last opportunity, as the cooperative could not create more contractual job opportunities since then.

\section{Permanent jobs}

Integrated Strategy for the Development and Promotion of Cooperatives (Republic of South Africa [RSA] 2012:12) defined permanent jobs as 'sustainable, long-term employment, where members earn a steady income'. According to the FGI conducted in this study, none of the cooperatives had created permanent jobs. Some of the reasons for this lack of permanent employment are related to lack of financial resources, false land promises and poor access to information and relevant training.

\section{Challenges on the creation of jobs}

Opportunities for creating seasonal jobs were found to be limited in the winter season for the cooperatives 
specialising in beading, welding and grass cutting. Their high dependence on governmental departments for opportunities in creating seasonal jobs was also noted. Because of inadequate financial resources, during FGI, cooperatives raised inability to hire any workers, despite reporting a workload that is beyond their capacity. The nature of their contractual jobs also seems to be highly dependent on external stakeholders, as they are unable to create contractual jobs on their own.

\section{Maintenance of steady income to members}

The Amathole District Municipality (Amathole District Municipality 2010:4, 25) described the steadiness of income as the ability to pay members regular permanent wages on a monthly basis. The FGI found out that none of the cooperatives were paying any salaries to members and that the Mooiplaas cooperative was unable to maintain a steady income for its members on a monthly basis. The emerging theme from the FGI was the heavy dependence of cooperatives on the government to survive. The challenges facing cooperatives were found to be more or less the same, regardless of their specialisation; all cooperatives do not have a steady income.

\section{Cooperatives and socio-economic development (livelihoods)}

\section{Findings}

Sizya (2001:4) argued that through cooperatives, income poverty could be alleviated by enabling cooperatives to improve the socio-economic development of communities (e.g. members' ability to pay school fees). Findings related to socio-economic development reveal tendency to use resources (e.g. finances) to solve immediate personal problems. Lopsided contributions from members (i.e. only certain members seem to carry the brunt of the financial burden for the cooperatives).

\section{Cooperatives and socio-economic development (employment)}

Through FGI it was established that temporary jobs allow a cooperative to hire labour from the community at a certain rate per day. The cooperative that specialises in welding, based in Duncan Village, also noted that there are more job opportunities during the summer season than in any other seasons. In 5 years, only two contractual jobs were created, with the last one offered in 2016.

\section{Cooperatives and poverty alleviation}

Mwelukilwa (2001:4) is convinced that there is no single definition of poverty as it is measured in several ways using various indicators. These indicators range from a lack of income and starvation to ill health. A study by Abbas (2016:265) analysed the relationship between cooperatives and poverty.

\section{Findings}

Only one cooperative in the FGI, from Scenery Park, specialising in agriculture, sewing aprons, pegs containers, headbands and lawn mowing shared positive comments on the role of cooperatives in poverty alleviation. A lack of governmental support in terms of adequate communication and information, follow-ups on commitments and resources were highlighted as challenges. The unresolved land issues by the municipalities contravene commitments alluded to in the Buffalo City ICDS (Buffalo City Metropolitan Municipality 2016:51).

\section{Cooperatives and poverty alleviation: Realities in Buffalo City}

In this context, the study is focused on how cooperatives contribute to reducing poverty. This could be measured by the extent to which cooperatives feed, clothe, house, access education and improve the social and economic life (Mwelukilwa 2001:4). Sizya (2001) noted the contribution of cooperatives to education through the payment of school fees. Sizya (2001) referred to one of the manifestations of poverty being sickness. This assertion agrees with Imoisili (2001:1) that symptoms of poverty include sickness and an inability to afford a doctor. Imoisili (2001:1) and Sizya (2001) also promoted the role of cooperatives in helping members afford a doctor's consultation.

\section{Findings}

The finding was on the ineffective role played by cooperatives in mitigating ill health. All cooperatives noted that they are still battling to support their families with accessing healthcare facilities. However, one agricultural cooperative (Scenery Park) indicated that the vegetables grown at the cooperative could be used in feeding those with ill health. Many also affirmed that if a cooperative is viable, there should at least be a certain amount of money that is invested in the bank. The investment should be utilised for purchasing the resources needed by the cooperative and for generating an income to pay wages of the members. Yet, in practice, the participants highlighted that there is no income, except that gained from a reliance on what has been sold on a particular day. Currently, there is no income available for taking care of those with ill health.

Findings also revealed that the manifestation of absolute poverty, specifically with respect to a lack of food (i.e. starvation), as alluded to by Abbas (2016:266), was alleviated through the provision of three meals per day. Regarding the contribution of cooperatives to education and affordability of basic services, the FGI revealed that cooperatives play no significant role. The main challenge noted by participants is the gaining and maintaining of cooperatives' financial viability and their current lack of income. Through EQ, with regard to poverty alleviation in terms of education affordability, the findings revealed 
that most cooperatives are involved in fashion design and often manufacture school uniforms and clothes for themselves. Still, this does not entirely contribute to the affordability of education, as members cannot sustain their business.

\section{Setting long-term goals and the participatory monitoring of cooperatives}

The aim of this section was to enable participants to think about the tangible benefits that have been achieved to signify the success of their respective cooperatives. In relation to the aforementioned challenges, these goals would, in fact, be the definition of success by the cooperatives. The long-term goals of the cooperatives were deliberated with regard to the following: profitability, sustainability, job creation and poverty alleviation.

\section{Findings}

One of the strategic pillars of cooperatives alluded to in the Buffalo City ICDS (Buffalo City Metropolitan Municipality 2016:61) is the creation of access to market. The strategic objective is to create opportunities for cooperatives to access and engage with markets through annual exhibitions and registering cooperatives in the $\mathrm{BCMM}$ database. The challenge that featured prominently in this discussion was in relation to marketing of cooperatives through branding, compliance with quality standards, tips and profit generation.

\section{Objectives and activities in all the areas raised as problems or challenges}

Estrella and Gaventa (1998:28) advocated the leadership of a researcher in guiding participants to define objectives and indicators considered best to solve a research problem. In the development of the indicator for this study, the SMART criteria (i.e. simple, measurable, action-orientated and timeframes) were considered. Following this approach, participating cooperatives agreed on the following objectives:

- To be a sustainable, profitable cooperative that creates jobs with access to market

- To comply with South African Bureau of Standards (SABS), where applicable

- To gain financial resources and training.

To achieve their objectives, cooperatives noted that they needed basic training in their areas of specialisation, training in $\mathrm{M} \& \mathrm{E}$, tools of trade and sufficient financial resources to buy the required equipment.

\section{Setting of indicators for success in measuring achievement of activities}

This section aimed to enable cooperatives to think about the tangibles that should be realised if a project is to be deemed successful. Because of no jobs having been created by any of the cooperatives, examining their achievements through indicators could not assist except to set long-term
TABLE 1: Analysis of long term goals, indicators and achievements.

\begin{tabular}{lll}
\hline Long-term goals & Indicators & Achievements \\
\hline Profitability & Output indicators & None \\
Sustainability & Number of cooperatives with business property & None \\
Job creation & Number of cooperatives marketing themselves & None \\
& Number of cooperatives trained in M\&E & None \\
& Number of jobs created & None \\
\hline
\end{tabular}

M\&E, monitoring and evaluation.

goals and offer a vision of success criteria, as recommended by Jobes (1997:4). After the definition of objectives and activities, Sokol-Oxman (2015:33) recommended an agreement upon indicators should be reached to measure success and failures. Hence, once deliberations on objectives were concluded, the next step was to reach an agreement on indicators. From the discussions, the list of aspired indicators agreed upon is listed in Table 1.

\section{List of aspired indicators}

Table 1 reflects that cooperatives have not achieved the aspired long-term goals.

\section{Participatory monitoring and evaluation and cooperative empowerment}

This section represented the extent to which PM\&E could capacitate and empower cooperatives in conducting M\&E, which the BCMM had not undertaken. One of the principles of PM\&E, as narrated by Estrella and Gaventa (1998:7), is to enable stakeholders to keep track of their progress and building on expanding areas of activities where success is recognised. The cooperatives acknowledged the problem of inadequate $M \& E$. The participants further suggested that the municipalities should have conducted situational analysis on areas of support for all cooperatives in the BCMM. In response to the research question seeking to measure the extent to which PM\&E could empower cooperatives in conducting M\&E, cooperatives suggested self-evaluation of their objectives for tracking their progress.

In response to the research question seeking to measure the extent to which PM\&E could empower cooperatives in conducting $\mathrm{M} \& \mathrm{E}$, cooperatives suggested self-evaluation of their objectives for tracking their progress. The aforementioned suggestions by cooperatives tie with PM\&E regarding organisational strengthening and institutional learning, as proposed by Estrella and Gaventa (1998:9), by enabling stakeholders to keep track of their progress by identifying and solving problems themselves.

\section{Challenges}

The government and municipal officials were said to be conducting sub-standard monitoring through site visits without any feedback to cooperatives. In fact, participants noted that M\&E is conducted within a narrow perspective through the conventional top-down approach. There is 
no PM\&E for public accountability where stakeholders themselves monitor or evaluate the performance of governmental institutions (Estrella \& Gaventa 1998:12). The problem investigated regarding inadequate $M \& E$ of cooperatives has not yet been resolved by the municipality.

\section{Participatory evaluation of cooperatives}

This section aimed at encouraging cooperatives to reflect on the impact of the project in their community in accordance with the study by Jobes (1997:8). Besides their existence, none of the cooperatives are succeeding in creating jobs. The challenge to job creation is attributed to lack of resources, especially for the cooperatives specialising in agriculture. For example, one participant noted that their vegetable yard is not secured and vegetables are stolen. There are also no water tanks for accessing water, and water is currently accessed from the nearest school. Additionally, there is inadequate funding and training, which remains a challenge.

\section{Role of municipality and government departments in supporting cooperatives}

The South African LED news (2011:1) referred to the various roles of municipalities in supporting cooperatives, ranging from champion to facilitator and trainer. The champion role is practised through the identification of members to form cooperatives. The facilitator role is offered in assisting community members in forming cooperatives. The Buffalo City ICDS (Buffalo City Metropolitan Municipality 2016:7) elucidated the role of BCMM in enhancing institutional capacity of cooperatives. To be specific, one agricultural cooperative in Duncan Village communicated in writing to the municipality 3 months ago, when the municipality advised them to communicate, instead, with the ward councillor. The role of governmental departments in supporting cooperatives was deemed ineffective by all cooperatives. The cooperative specialising in piggery and catering in Mooiplaas forwarded a formal correspondence to the BCMM in the form of a letter to be forwarded to the councillor. To date, no response has been received from the municipality except to reject calls when doing follow-ups.

All cooperatives, except the one specialising in the manufacturing of soap, were very dissatisfied with the role of the municipality and other relevant stakeholders in the M\&E of cooperatives. Only the cooperative manufacturing soap was provided with training.

\section{Cooperative governance: Realities in Buffalo City}

This section aimed to allow cooperatives to share any support by two government departments, that is, the DEDEA and the Department of Cooperative Governance and Traditional Affairs (COGTA). Maskur (2015:499-500) put emphasis on the role of local government in developing primary cooperatives. Rogerson (2010:40) described the role of the local government in LED programmes of various countries in Europe and North America. This author noted that local government should manage and exploit the existing potential and establish partnerships with private sector. Such partnerships aim to create jobs, promote economic development and alleviate poverty.

\section{Findings}

No support was acknowledged by cooperatives, specifically with regard to support by both COGTA and DEDEA, except for false promises. The cooperatives highlighted that they need support from COGTA. In addition to the provision of resources, there is also a need for monitoring business operations by departments or municipalities until cooperatives are sustainable.

\section{Emerging issues}

\section{Category 1: Capacity limitations in areas of cooperative specialisation}

The codes that featured prominently, giving rise to the categories, were: (1) capacity limitations in the very same areas of specialisation and training needs for cooperatives in financial management and (2) M\&E. In addition, there was a need for capacity building through training in areas of specialisation, marketing and financial management. It was found that the members in leadership positions of the cooperatives have inadequate knowledge of cooperatives. One of the barriers they face is inadequate access to markets; most cooperatives are still facing challenges with regard to marketing their produce. The intention of the fourth strategic pillar number outlined in the Buffalo City ICDS (Buffalo City Metropolitan Municipality 2016:47) is to create access to markets through organising annual exhibitions, developing newsletters and creating a database of goods and services. It seems that the fourth strategic pillar has not been achieved.

\section{Category 2: Inability to create jobs and payment of salaries}

The codes identified were: (1) inability to create jobs or pay salaries to members, (2) high dependency on government in creating contractual jobs and (3) limited opportunities that could contribute to job creation. With regard to the creation of contractual jobs, the literature findings from the study by Abrahams (2009) could not draw any similarities, as the cooperatives interviewed during the FGI are highly dependent on government for the creation of contractual jobs. The findings revealed during the FGI indicated an inability to create temporal, contractual and permanent jobs. In addition, the FGI revealed an inability of cooperatives to pay salaries to their members. These findings were in line with the literature review (e.g. Amathole District Municipality 2010:24, 2016:53), where job creation by cooperatives was emphasised, but noted as still, unfortunately, being an issue. 
With regard to the creation of permanent jobs, the literature findings alluded to by the Amathole District Municipality (Amathole District Municipality 2010) were also contradicted, because of the inability of cooperatives in creating permanent jobs and a lack of remuneration of members. The challenge of accessing the market featured prominently, even though this particular point has been established as one of the measurable indicators and targets for cooperative development by the DTI (RSA 2004; 2012) with regard to increasing cooperatives' access to markets. This finding is contrary to the measurable indicators, as the market challenges have not yet been resolved.

\section{Category 3: Inadequate support from the municipality}

The FGI conducted through pilot and main research revealed lack of input resources and prerequisites for success of the cooperatives in delivering outputs. These resources include a lack of sewing machines and access to land.

The findings regarding the role of the municipality in supporting cooperatives were said to be inadequate and contrary to municipal support defined by South African LED news (2011) as facilitator, broker, trainer and spatial planner. The FGI revealed contrary information to the findings by the Buffalo City ICDS (Buffalo City Metropolitan Municipality 2016:50) has made a commitment to resolving issues of land ownership. These issues have not yet been finalised, leading to denied support to cooperatives by other governmental departments.

\section{Category 4: Lack of monitoring and evaluation}

The first recurring code in this category was malicious compliance by governmental departments when conducting site visits. The second one was a lack of regular feedback and follow-ups by governmental departments, even with regard to those site visits conducted. The emerging finding was that there is a lack of M\&E related to the contribution of cooperatives in addressing unemployment. There is a match between findings revealed during the FGI and the literature gaps identified in the Buffalo City ICDS (Buffalo City Metropolitan Municipality 2016:49) because of inadequate M\&E, which is still a problem.

\section{E-mailed questionnaires}

Bless et al. (2016:195) suggested EQs as a possible data collection instrument. This kind of questionnaire can be e-mailed to respondents and then returned, via email, to the interviewer. One of the prerequisites of EQ is sufficient literacy and familiarity with the language used (Bless et al. 2016:199). Du Plooy-Cilliers, Davis and Bezuidenhout (eds. 2014:150) also recommended EQ, because it is less expensive than other questionnaire approaches. The design of this study's questionnaire included an introduction consisting of an explanation and reasons for conducting the study.

\section{Findings on the contributory role of cooperatives in promoting local economic development manifested in job creation}

\section{Seasonal jobs}

The findings deduced through the EQ revealed that most registered cooperatives do not operate under seasonal periods, as they are mainly concerned with manufacturing (e.g. brick making, crafting or cleaning products) and ploughing tomato channels. The challenge is that cooperatives do not invest in the business, but rely on hand to mouth and because of poverty they need cash on an immediate basis. This is a challenge, as cooperatives need income on a monthly basis for the purpose of supporting their families.

\section{Contractual jobs}

The International Labour Organisation (ILO) (2013:2) noted the advantages of cooperatives in affording a group of workers to negotiate contracts. The Amathole District Municipality (Amathole District Municipality 2010:24) referred to the Sisonke Bakery Cooperative located in Keiskamahoek and noted that the cooperative did not have any customers because of perceived refusal by local shop owners to buy their bread. As a remedial measure, the cooperative negotiated a contract with a school feeding scheme for its market. However, the finding in this study was that most cooperatives have not managed to secure contracts successfully, which further affects their sustainability and financial viability.

\section{Temporary jobs}

Participants noted that fewer temporary jobs are created because of a lack of capital to boost the cooperatives.

\section{Permanent jobs}

Hertig (2008:2) defined permanent jobs as the stability of employment, where members can derive income from services, security at workplaces and pension funds. The Amathole District Municipality (Amathole District Municipality 2010:24) shared a lesson on how the Sisonke Bakery Cooperative was formed and contributed to permanent jobs. During the initial formation of the Sisonke Bakery Cooperative, members contributed R300 as start-up capital, with the aim of employment creation for members. The cooperative created permanent jobs and members ended up earning around R1500 per month. However, the challenge facing cooperatives in this study includes a lack of financial stability.

\section{Jobs created by cooperatives for the purpose of benefiting non-cooperative members}

The findings revealed by the municipal officials on that the creation of jobs for the purpose of benefitting noncooperative members was said to be limited. Job creation of this nature was said to be a challenge. Very few cooperatives are able to create jobs for themselves on a sustainable basis. 

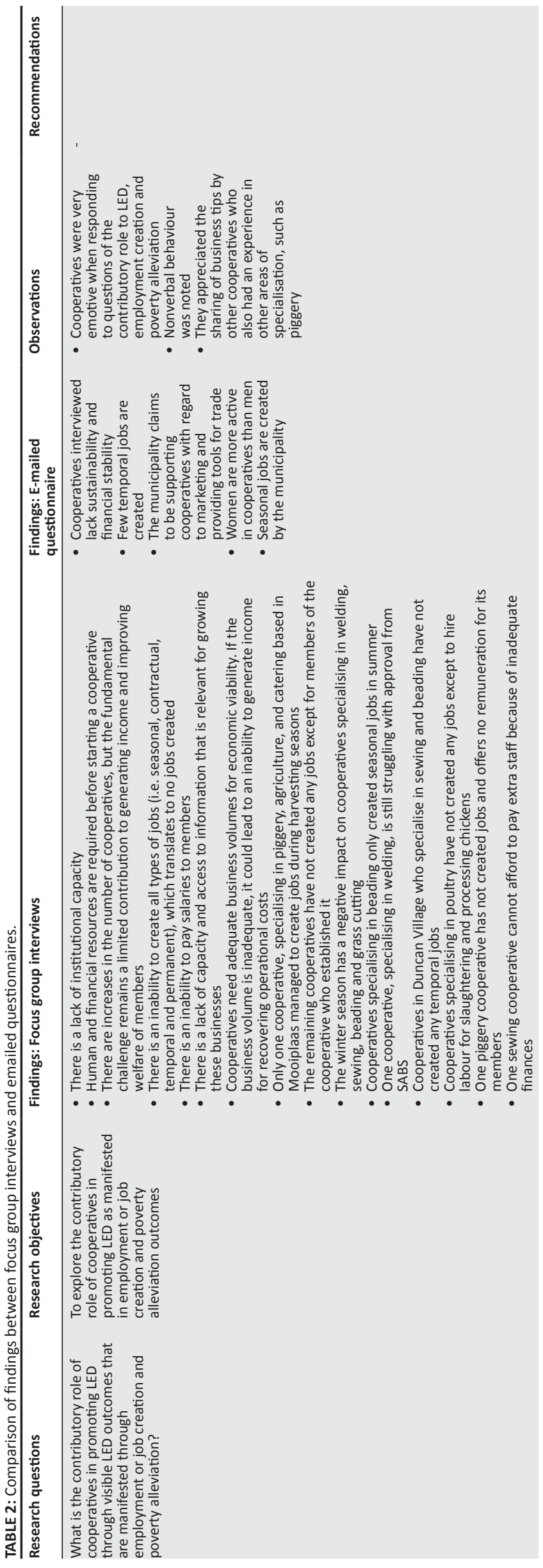
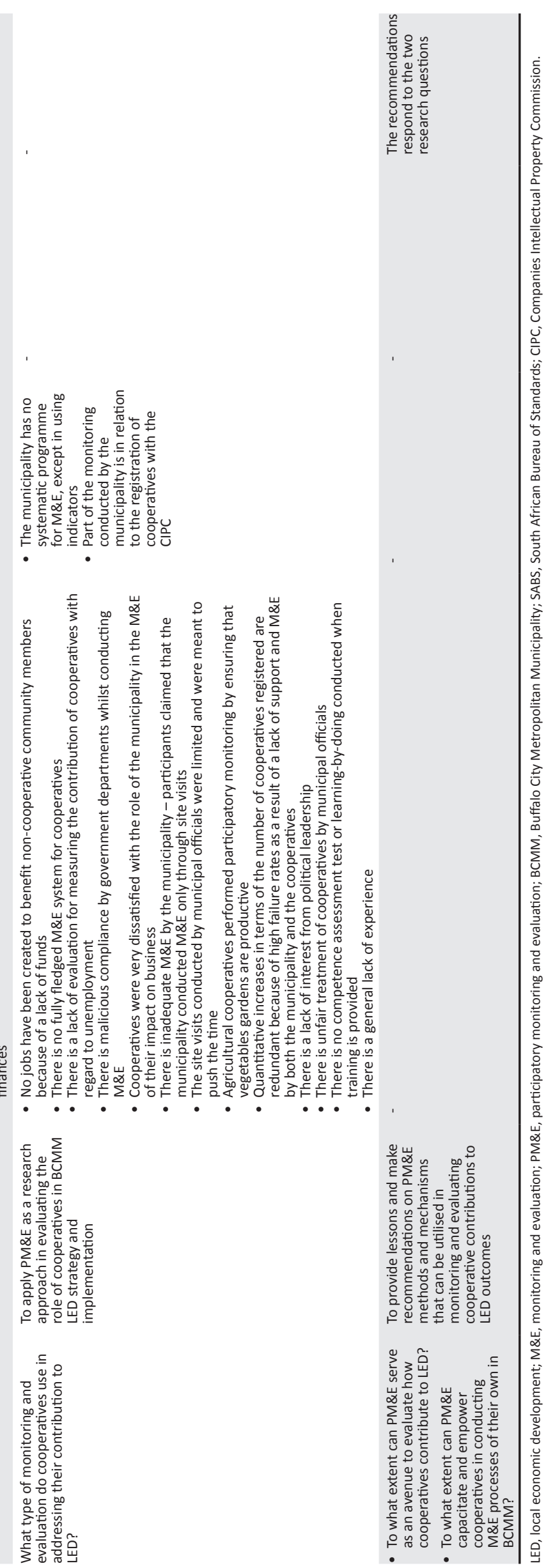


\section{Key findings}

Table 2 compares the research questions, research objectives and findings of the FGI and EQ.

\section{Strengths and limitations of methods Strengths}

Integration of two methodologies (i.e. PAR and PM\&E) when conducting the research. Application of PAR and $P M \& E$ in the development context by sharing empirical evidence on feasibility thereof. Both methodological (PAR and PM\&E) frameworks prioritise the marginalised by emphasising participation and development through bottom-up approach by engaging relevant stakeholders. Both methodologies prefer piloting, exploratory research design and qualitative research methodology.

\section{Limitations}

The shortcomings in PAR is the lack of indicators that will measure the deliverables. The challenge with PM\&E is lack of common definition of PM\&E. What is common with PM\&E is active participation of stakeholders in defining what will be monitored.

\section{Recommendations}

The recommendations are:

- There is a need for capacity building training, which is viewed as relevant and important in assisting cooperatives to fully understand the businesses they are running

- The municipality should conduct an audit of all cooperatives in BCMM for the purpose of ascertaining resources and support needed

- Apart from registering cooperatives, the municipality still needs to monitor the formation of cooperatives, operations and growth

- There is a need for the coordination of training and support rendered to cooperatives by various government departments rather than duplication of responsibilities and competition

- Sessions where cooperatives share lessons, successes and failures could assist them in adding value to their businesses in the presence of stakeholders

- Training cooperatives with respect to PM\&E could further assist them in monitoring their indicators and identifying similarities between indicators aspiring growth, and access to required resources for running a cooperative in the form of financial resources and business property.

\section{Conclusion}

From the findings presented, it was established that cooperatives have not yet achieved their contributory role of promoting LED, specifically in terms of job creation. There is lack of institutional capacity and sound experience and financial resources required before establishing a cooperative. There is also no M\&E of cooperatives conducted by the municipality. A good number of cooperatives have not successfully created contractual, seasonal, temporal or permanent jobs and most cooperatives are not earning a stipend or any form of salary. There is lack of support and interest from political leadership, yet the municipality officials claim to be supporting cooperatives to participate in various provinces through expos and cultural festivals.

\section{Acknowledgements}

The authors would like to acknowledge Nombulelo Maliza, Ngenanimazizi Sidinana, Queen Nosizwe Siwani, Tshililo Vele and Nosivatho Matewu for their support in writing this article.

\section{Competing interests}

The authors declare that they have no financial or personal relationships, which may have inappropriately influenced them in writing this article.

\section{Authors' contributions}

F.G. and O.N. contributed equally to the work.

\section{Ethical consideration}

This article followed all ethical standards for carrying out research, with clearance received from the University of Fort Hare: REC-270710-028-RA Level 01.

\section{Funding information}

This research received a bursary from the Eastern Department of Cooperative Governance and Traditional Affairs.

\section{Data availability statement}

Data sharing is not applicable to this article as no new data were created or analysed in this study.

\section{Disclaimer}

The views and opinions expressed in this article are those of the authors and do not necessarily reflect the official policy or position of any affiliated agency of the authors.

\section{References}

Abbas, A.I., 2016, 'The roles of cooperative societies in alleviating poverty in Yobe state, Nigeria', International Journal of Political Science and Development 4(7), 264-275. https://doi.org/10.15640/jsspi.v4n1a3

Abrahams, C., 2009, Cooperative enterprises as a solution to rural poverty and unemployment case studies of the Heiveld cooperative at Nieuwoudtville in the Northern Cape and Die Berg Vrugteverwerking at Piketberg in the Western Cape Province, University of the Western Cape, Cape Town.

Ali, H. \& Birley, S., 1998, 'Integrating deductive and inductive approaches in a study of new ventures and customer perceived risk', Qualitative Market Research: An InternationalJourna/2(2),103-110. https://doi.org/10.1108/13522759910270016

Amathole District Municipality, 2010, The cooperative case studies of Amathole District Municipality, Amathole District Municipality, Amatole region.

Barbie, E. \& Mouton, J., 2017, The practice of social research, South African edn., Oxford University Press, Cape Town. 
Bless, C., Higson-Smith, C. \& Sithole, S.L., 2016, Fundamental of research methods: An African perspective, 5th edn., Juta, Cape Town.

Buffalo City Metropolitan Municipality, 2016, Buffalo City Metropolitan Municipality Integrated Cooperative Development Strategy, Amathole District Municipality, Amatole region.

Chakrabarty, B. \& Chand, P., 2015, Public administration in a globalizing world: Theories \& practices, Sage, London.

De Vos, A.S., Strydom, H., Fouche, C.B. \& Delport, C.S.L., 2011, Research at grassroots level, 4th edn., Van Schaick, Cape Town

Dilshad, R.M. \& Latif, M.I., 2013, 'Focus group interview as a tool for qualitative research: An analysis', Pakistan Journal of Social Sciences 33(1), 191-198.

Du Plooy-Cilliers, F., Davis, C. \& Bezuidenhout, R. (eds.), 2014, Research matter, Juta, Cape Town.

Du Toit, D.F.P. \& Van der Waldt, G., 2008, Public administration \& management: The grassroots, 2nd edn., Juta, Cape Town.

Eastern Cape Department of Economic Development \& Environmental Affair (DEDEA), 2008, South Africa: Strategy and implementation plan for support and development of Co-operatives in the Eastern Cape Province. The Department of Economic Development and Environmental Affairs (DEDEA), King William's Town.

Eckert, A., 2007, 'Useful instruments of participation? Local government and cooperatives in Tanzania, 1940s to 1970', The International Journal of African Historical Studies 40(1), 97-118

Estrella, M. \& Gaventa, J., 1998, 'Who counts reality? Participatory monitoring and evaluation: A literature review', International Workshop on Participatory Monitoring \& Evaluation, viewed n.d., from https://opendocs.ids.ac.uk/opendocs/bitstream/ handle/20.500.12413/3388/Wp70.pdf?sequence=1\&isAllowed=y

Greeff, M., 2011, Research at grassroots: For the social sciences and human services professions, 4th edn., Van Schaik, Pretoria.

Guijt, I. \& Hillhorst, T., 2006, Participatory monitoring and evaluation: A process to support governance and empowerment at the local level, A guidance paper, Royal Tropical Institute, Amsterdam.

Hertig, M.E., 2008, The contribution of cooperatives to employment creation, pp. 1-9, International Labour Organization Cooperative Branch, Geneva.

Imoisili, I.C., 2001, 'The role of cooperatives in poverty alleviation', in 44th Annual International Convention/30th Annual General Meeting of the Caribbean Confederation of Credit Unions, CCCU, vol. 18, Maho Beach Resort, St. Maarten, 18 July 2001, Netherlands Antilles, West Indies.

Ismail, Z. \& Kollamparambil, U., 2015, 'Youth unemployment duration and competing exit states: What hides behind long spells of black youth unemployment of South Africa?', African Development Review 27(3), 301-314. https://doi.org/10.1111/ 1467-8268.12150

International Labour Organization, 2013, Cooperatives and the world of work No. 2, viewed n.d., from https://www.ica.coop/sites/default/files/publication-files/iloand-cooperatives-no2-2013-426880983.pdf

Jobes, K., 1997, Participatory monitoring \& evaluation guidelines: Experiences in the field: St Vincent and Grenadines. The Community Development Division, Ministry of Housing and Development Services, London.

Kumar, R., 2014, Research methodology: A step by step guide for beginners, 4th edn., Sage, London.

Lacey, A. \& Luff, D., 2009, Qualitative data analysis, University of Sheffield, National Institute of Health Research, Sheffield.

Manciya, S., 2012, 'The impact of the new co-operative act on employment and poverty reduction: A case study of sorghum producers in the Eastern Cape Province', MSC, University of Fort Hare.

Maree, K., 2008, First steps in research, Van Schaik, Pretoria.

Maskur, A., 2015, 'Local government action for developing primary cooperatives in Indonesia', 3rd Global Conference on Business \& Social Science, 16-17 December 2015, Kula Lumpur, Malaysia.
Mtshwelo, L.H., 2014, 'An assessment of the roles co-operatives as agents of development in rural areas: A case study of Inkwanca Local Municipality', Doctoral dissertation, University of Fort Hare, Alice.

Mugunya, G., 2002, Applying participatory monitoring and evaluation (PM\&E) approaches to weapons for development programmes: A report on the conference of small arms and light weapons of human security; lessons learned from field experiences, United Nations Institute for Disarmament Research, Geneva.

Mwelukilwa, J., 2001, 'The role co-operatives play in poverty reduction in Tanzania', paper presented at the United Nations in observance of the International Day for the Eradication of Poverty, 17 October 2001, Moshi.

Neuman, W.L., 2014, Social research methods: Qualitative \& quantitative approaches, 7th edn., Pearson, London.

Pante, B.L., Matocinos, A., Abril, A. \& Servito, B., 2013, 'Perspiratory action research in disaster preparedness and community reconstruction', Philippine Sociological Review 61(2), 419-444.

Rogerson, C.M., 2010, 'Planning local economic development', Africa Insight 32(2), $39-45$.

Republic of South Africa (RSA), 1996, Constitution of the Republic of South Africa (Act 108 of 1996), Government Gazette No. 25799, Government Printing Works, Pretoria.

Republic of South Africa: Department of Trade \& Industry, 2004, A co-operative development policy for South Africa: 2004, viewed n.d., from http://www. ilembechamber.co.za/wp-content/uploads/2017/12/Co_operativeDevelopment-Policy.pdf

Republic of South Africa: Department of Trade \& Industry, 2012, The Integrated Strategy on the Development and Promotion of Cooperatives. Promoting an Integrated Cooperative Sector in South Africa 2012-2022, viewed n.d., from http://www.thedti.gov.za/parliament/IntegratedCooperatives.pdf

Sangole, N., Kaaria, S., Jemimah, N., Lewa, K. \& Mapila, M.A., 2014, 'Community based participatory monitoring and evaluation: Impacts on farmer organization functioning, social capital and accountability', Journal of Rural and Community Development 9(2), 128-148.

Savin-Baden, M. \& Wimpenny, K., 2007, 'Exploring and implementing participatory action research', Journal of Geography in Higher Education 31(2), 331-343.

Sizya, M.J., 2001, The role of cooperatives in poverty reduction, Department of Economic and Social Affairs, viewed n.d., from https://www.un.org/esa/socdev/ social/papers/poverty_panel_sizya.pdf

Sokol-Oxman, L.S., 2015, Implementing of participatory approach to monitoring and evaluation: Literature review \& case study application, School for International Training, Graduate Institute, Washington, DC.

South Africa, Department of Trade \& Industry, 2004, A co-operative development policy for South Africa, viewed n.d., from https://pdf4pro.com/view/a-co-operativedevelopment-policy-for-south-africa-157f4e.html.

South African LED News, 2011, Cooperatives a local government approach, vol. 3 , pp. 1-7, South African Local Government Association, Pretoria.

Strydom, H. \& Delport, C.S.L., 2011, Sampling \& pilot study in qualitative research: Research at grass roots level for the Social Sciences \& Human Service Profession, 4th edn., Van Schaik, Cape Town.

Terre Blanche, M., Durrheim, K. \& Painter, D., 2006, Research in practice: Applied methods for the social science, 2nd edn., UCT Press, Cape Town.

Vellem, B.F., 2012, 'Assessing the role of cooperatives in poverty alleviation in the Eastern Cape case study of Amathole District Municipality', Master's in Public Administration, University of Fort Hare, Alice.

Wallis, M. \& Reddy, P., 2012, 'Local economic development: A critique of the African experience', Politeia 31(2), 70-88.

Zeuli, K.A. \& Radel, J., 2005, 'Cooperatives as a community development strategy: Linking theory and practice', Journal of Regional Analysis and Policy 35(1), $43-54$ 